$=$

\title{
Is there a post-Marxist criticism to the decolonial critique?
}

\author{
Dennis Stromback, \\ University of Minnesota
}

Abstract

\author{
Journal of Decolonising Disciplines \\ Vol 1 No 22019 \\ eISSN: 2664-340 \\ Issue DOI: \\ https://doi.org/10.35293/jdd.vli2 \\ Article DOI: \\ https://doi.org/10.35293/jdd.v1i2.24
}

This article makes explicit a hidden tension between post-Marxism and decolonial studies, which points to a challenge for intercultural dialogue. While post-Marxism seeks to rehabilitate a universal foundation for the construction of truth claims-a universal already formed within Western modernity-the decolonial critique seeks to dismantle all universals connected to the myths of modernity and therefore demands a departure from the standpoint of the cultural periphery. In fact, Alain Badiou and Slavoj Žižek, like other post-Marxists, have been rather critical of the standpoints articulated by decolonialists who strive to include cultural differences and marginalised identities in the process of knowledge production, but the reality is that the decolonial critique, more so than post-Marxism, is well-supported by the historical evidence, thus demonstrating the need for what Enrique Dussel calls a 'transmodern pluriverse' in the academic world. In pursuit of diffusing this tension between the post-Marxists and the decolonialists, this article calls for further investigation in terms of determining if real dialogue is possible between these two trajectories of thought.

Keywords: post-Marxism, transmodernity, decolonisation, the myth of modernity 


\section{Introduction}

In his article 'Post-Marxism and religion', Nelson Maldonado-Torres (2017: 457), a well-known scholar in decolonial studies and the philosophy of liberation, discusses the 'theological turn' within post-Marxism, citing Alain Badiou, Antonio Negri and Slavoj Žižek as major theoreticians who 'contribute further to this complex relationship between Marx's thought, the critique of capitalism, and religious discourse'. Even though Maldonado-Torres (2017: 468) does not necessarily endorse any of these thinkers as such, stating that 'only time will tell if these theoretical movidas will mark post-Marxism as a necessary and important source in the struggle against myriad forms of domination and exploitation, or if they will further isolate this discourse', left unmentioned in this discussion is the underlying tension that exists in the approach of such theorists to the philosophy of liberation and the decolonial critique. ${ }^{1}$ In fact, Alain Badiou and Slavoj Žižek in particular, have frequently directed harsh criticism against philosophies that either take an 'ethics-first' methodology or seek to generate a more relativist approach to the universal. ${ }^{2}$ While both camps-the post-Marxists and the decolonialists - share the common struggle of fighting against the various forms of domination, the gap between them is at times difficult to overestimate: simply compare Badiou, who is involved in developing a mathematical ontology that hopes to provide a new way of thinking about multiplicity, and Žižek, who is seeking to give Marxism a Lacanian basis for thinking through the symptoms of the fantasy of global capitalism, with Enrique Dussel, who combines the philosophy of liberation and the philosophy of Levinas and Marx in an attempt to subvert any universal truth claim that quietly champions Western modernity as the centre of knowledge production. In the end, Dussel is a particularist who confers a universal only among the very particulars themselves by means of empowering alterity, while the postMarxists seek to reclaim a universal foundation from within Western modernity. The criticisms proffered by Badiou and Žižek are loud and clear: there is a need to go beyond the modern and post-modern paradigms through the development of a third position that is universal and yet resistant to relativist truth claims, but what is not necessarily included in these visions of 'moving beyond the duality' is Dussel's transmodernity. While the former certainly appeals to Dussel's intellectual and ethical sentiments, at the same time however, any return to European ontology that could recuperate epistemological racism will certainly find resistance from Dussel and the decolonialists. 
In the article 'Enrique Dussel's Transmodernism', Linda Martín Alcoff (2012: 61) touches on some of the meta-philosophical issues in Dussel's work and mentions that Dussel has in the past responded to the charges made by theorists like Badiou and Žižek, but has since moved on. It is true that Dussel mentions Badiou a few times throughout his oeuvre, often reading him in the service of the decolonial agenda (see Dussel 2019: 13) — which can be taken as diplomatic and strategic - but there also seems to be little concern for Badiou's scorn for cultural criticism. This is indeed a shame because there is something of value in Badiou's (and Žižek's) assessment of the 'cultural critique'-this concern for collapsing truth and linguistic judgment-but at the same time what is largely ignored in both Badiou's (and Žižek's) philosophical reclamations is the historical evidence that supports Dussel's theoretical formulation and the decolonial agenda. Therefore, it is fair to suggest that Badiou and Žižek's philosophy have yet to move beyond the terrain of 'mere hypothetical speculation' in this regard. And so, in this article, I will argue that there is still a need to make explicit the implications of the post-Marxist critique on Dussel's critical methodology and vision of transmodernity, and vice versa, with the hope that such an investigation will inspire scholars in decolonial studies and the philosophy of liberation to further investigate the implications and challenges among decolonialists seeking to build dialogue with the post-Marxists.

\section{Post-Marxism and the cultural critique}

Badiou's work contains many disparagements directed at the cultural critique. In Saint Paul: The foundation of universalism, he describes the contemporary philosophical situation as a problem of 'communitarianisms' rivalling for hegemony, which amounts to

[t]he progressive reduction of the question of truth (and hence, of thought) to a linguistic form, judgment-a point on which Anglophone analytical ideology and the hermeneutical tradition both concur (the analytical hermeneutic doublet is the straightjacket of contemporary academic philosophy) —ends up in a cultural and historical relativism that today constitutes at once a topic of public opinion, a "political" motivation, and a framework for research in the human sciences. (Badiou 2003: 5-7) 
While there is a lot to unpack here, ultimately what Badiou is claiming is that the cultural critique, which includes decolonial studies in general, assumes a cultural relativism to the point where there is a conflation of 'victimhood' and the 'culturalist ideology', meaning that all cultural critiques depend on the status of being a 'victim' of power. The problem is that if all cultural ideologies begin from a stance of victimhood, all ideologies outside of the victim are the dominators of power, and with all cultural ideologies assuming access to the universal itself any real distinction between dominator and victim will remain obscure, if not meaningless. In the 'extreme forms of this relativism', as Badiou (2003: 6) adds, is the 'claim to relegate mathematics itself to an "Occidental" set up. This is all because, according to Badiou (2006: xii), viewpoints affirming cultural relativism or cultural differences cannot go beyond their own linguistic judgments, and the claim that only different situations exist 'does not tell us anything about what, among the differences, legitimately matters to subjects'.

Fair enough. To assert this extreme claim, such as that mathematics being nothing more than a Eurocentric projection, deserves the wrath of Badiou's scathing critique, but this is not what Dussel and the authors of decolonial studies have been arguing and which I will attend to in more detail in the next section. Furthermore, Badiou is only one among many who are hostile towards positions like the decolonial critique: Žižek has been equally harsh in the treatment of an 'ethics-first' philosophy and in fact claims that such approaches participate more broadly within a constellation of discourses that reduces the ideological scene to 'a panoply of positions which struggle for hegemony, where the underlying consensus is opposed to all foundationalism' (Žižek 2008: 1). The concern for Žižek (2008: 3) is 'how to redeem the emancipatory potential of these failures [the dialectics of theory and practice] through avoiding the twin trap of nostalgic attachment to the past and of all-too-slick accommodation to "new circumstances". This may not seem like a lashing out against the decolonial critique as such, but the devastating criticisms Žižek has incited towards Levinas tells us otherwise. In Neighbors and other monsters: A plea for ethical violence, Žižek (2005: 160) is upfront about his contempt for a Levinasian approach to philosophy, arguing that Levinas fails to take into account the 'radical, "inhuman" Otherness itself', that which is 'a dimension which eludes the face-to-face relationship of humans' (2005: 158). Here Žižek is trying to shine a critical light on how the 'radical, inhuman' dimension of human life can allow for legitimising violence in the name of a greater freedom. As Žižek (2005: 186) says, 
'freedom is not a blissfully neutral state of harmony and balance, but the violent act which disturbs this balance'. In other words, a Levinasian ethics-first philosophy, which is really about respect and responsibility toward the Other, remains stuck in a cycle of 'understanding the Other' (2005: 184). The problem then is the reduction of ethics to a lack in communication within intersubjectivity. If we are locked within a circle of intersubjective communication, it becomes nearly impossible to legitimise the necessity of violence that would otherwise unmask the violence generated from within the de facto system. We may understand the Other at the end of the day, but it does not make explicit the institutions of power (e.g., capitalism) that demand us to take the next step in the ethical injunction of going beyond non-violence and fighting violence with violence, because the 'true ethical step is the one beyond the face of the other, the one of suspending the hold of the face, the one of choosing against the face, for the third' (Žižek 2005: 183). Making the 'third' (the universal) visible allows this ethical step to be justified.

Dussel (2006: 87) has of course also been critical of Levinas, even on similar grounds, describing his phenomenological ethics as insufficient in meeting the needs of the historically contingent people of the world, which is why the emancipatory project must be politicised and placed at the service of the Other, the poor, the widow, the stranger' $-\mathrm{a}$ view appropriated from liberation theology. However, the point Žižek is making is not only against Levinas's anti-political formulation and the problematic sociopolitical consequences of an ethics-first philosophy, but the 'smuggled ontology' within a stance that is aggressively anti-ontologist. Žižek (2005: 184) claims that there is a hidden universal in the background of Levinasian justicethat prior to a relationship with an Other there is a faceless third. This is not an a priori universal, but a constitutive universal (à la Kant) that grounds Levinas's ethics in the Other's face, a universal that makes possible the particularities making truth claims (not just the particulars in the form of subjectivity, but in the form of cultural ideologies). If we briefly return to Badiou, we can see what is meant by 'the reduction of the question of truth to a linguistic form [of] judgment', and that if we assume that the signifier-signified relationship has empirical equivalences in reality, all questions of truth remain in the domain of the particulars and each cultural ideology calling victimhood is no greater than any other, leaving the de facto ideology to exercise the privilege of intellectual judgment (i.e., the ideology of global capitalism). The implication of what Badiou and Žižek are arguing is that without a clear universal, grounding philosophical truth, even the decolonial critique could end up in a pyrrhic 
victory, as in the case of post-modern criticism becoming the new universal within the academic world. One might think of the co-option of left-wing ideologies by hegemonic powers to dominate the 'excluded other' as a glimpse of what Badiou and Žižek have in mind. Hence the need for a universal qua 'third position' that does not foreclose multiplicity while remaining resistant to post-modern relativism.

Arguments of this kind have circulated rather widely among Marxist sympathisers within contemporary theory. Marxist geographer David Harvey (1990), for instance, argues that relativist theoretical positions celebrating differences as a mode of inquiry in the academic world are actually driven by capitalist production. Since the production of theory cannot be detached from material production within a system of capitalism, there is a danger in allowing for universal truth claims to be replaced by multiplicity, because if we accept a stance of pluralistic voices of 'other worlds', we will inherit the acute problem of 'reducing knowledge and meaning to a rubble of signifiers' and thus produce 'a condition of nihilism that prepared the ground for the reemergence of a charismatic politics and even more simplistic propositions than those which were deconstructed' (Harvey 1990: 350). The solution to this problem cannot be more fragmented and plural since, as Harvey (1990: 355) argues, the theoretical approach to differences and 'otherness' should not be 'something to be added on to more fundamental Marxist categories (like class and productive forces), but as something that should be omni-present from the very beginning in any attempt to grasp the dialectics of social change'. Like Harvey's critique of cultural criticism, John Sanbonmatsu (2004) also argues for a need to 'reconstruct a theory of totality' by positioning historical materialism as the engine of ontological production. Towards this end, Sanbonmatsu faults cultural studies (such as post-colonialism) as a whole for the excess of relativism today, which promotes the idea that reality is an eruption of differences. Sanbonmatsu (2004: 117-118) tells us that cultural studies in fact mimic the viewpoint of the Young Hegelians who strive to correct illusory consciousness, which is something Marx warned us against, because they obscure the real material forces at work in the production of ideology by virtue of only using phrases to combat other phrases.

We might think that none of these criticisms apply to the decolonial critique, especially given that Dussel and much of liberation theology was inspired by Marxism, and that the criticisms of the post-Marxist camp are generally aimed at post-structuralism. However, there is indeed some merit to this view and so we must be careful not to construct a straw man. On the other hand, Dussel's defence of 
cultural differences and marginalised identities with no desire to rebuild a European style universalism might just appear a little too 'post-modern' for the average postMarxist. For the time being then, decolonial studies are somewhat 'off the hook' from being under the surveillance of the Marxist critique. While an alliance could occur between the decolonialists and the post-Marxists, there is no doubt that as the struggle against oppression and domination continues, tension and scuffle between them will arise in the formation of hegemonic action. Neither Harvey nor Sanbonmatsu, for instance, rejects modernity tout court, and Badiou and Žižek have no plans to renounce their projects to rebuild a new universal within Western philosophy. Meanwhile Dussel is advancing a transmodern pluriverse in an attempt to discard and replace the universal myth of modernity that situates Europe as its epicentre and thereby removing any possibility to regenerate any totalizing system of thought. To the run-of-the-mill post-Marxist, the decolonial critique will most likely be viewed as another participant of the 'war on totality' that fears utopia and revolutionary politics, because it associates such events with the 'turn to Terror' (Jameson 1991: 401). ${ }^{3}$ As a result, the decolonial approach would be relegated to the 'soft war' against global capitalism. But such a scenario would be a misunderstanding of the decolonial critique, because for decolonial studies, and certainly for Dussel, this 'war on totality' is not at all a fear of utopia and revolutionary politics; on the contrary, this war begins from a critical position within the world that is more radical and far-reaching than what Marxists have ever imagined since its approach to revising the project of modernity is based on a historical critique of European epistemology - a critique that precedes, and is therefore more fundamental than the Marxist worldview, which I will now discuss.

\section{Dussel and the historical critique of Western epistemology}

In 1492 El encubrimiento del Otro: Hacia el origen del 'mito de la Modernidad' (1994), which is arguably one of Enrique Dussel's most important works, European modernity is discussed as having embodied hidden assumptions about itself and the world in its pursuit of emancipating the Other via reason. This is because modernity is really a European occurrence, and its origins are in a dialectical relationship with the non-European Other. There is a centre-peripheral issue that is important for understanding how the myth of modernity is developed here. That is to say, European modernity is the result, and not the cause of subjecting the Other to conquest and 
control, which is what led Europe to place itself at the centre of the world (or at the end of history) and the periphery in a state of immaturity. Therefore, as Dussel (1994: 21) argues, modernity does not begin in the 16th or 17th century in Northern Europe, as often framed in the academic literature, but in 1492 with the 'discovery' and conquest of the Americas. Descartes's Cogito, which is normally thought of as the beginning of modernity, turns out to be its culmination, situated as the great thinker of the second moment of early modernity, because it reflects a view of the world from the standpoint of European subjectivity after the domination of the Americas (Dussel 1994: 11). In Levinasian fashion, Dussel (1994: 39) emphasises that there never was a real European discovery of the Americas qua discovery of the Other as Other, but rather a covering over (encubierto) of the Other by denying its (cultural) differences or reducing them to that of the Same.

Dussel (1994: 175-177) identifies two myths in the historical development of modernity. The first is that modernity represents itself as a rational emancipation from a state immaturity, and the second is the rationalisation of (irrational) violence in the name of modernity. According to Dussel, quilted within the myth of modernity is a Eurocentric viewpoint that assumes modernity represents the pinnacle of development. Such a view of self-declared superiority then convinces itself of the need to develop the primitive and barbaric along the lines of European culture to the point of using violence to ensure that this civilising process takes place without too much opposition. The sacrificial victims of the colonising process are framed as the 'inevitable costs of modernization' and it is asserted that it is the barbarian's and primitive's own fault for resisting the modernisation project. Ultimately, what Dussel's unmasking of the origins of modernity is pointing to is the need for the ethical commitment to the victims of modernity and colonial conquest because the myth of European modernity itself, which shapes the discourses of contemporary philosophy, forecloses the necessity of cultural differences and marginalised identities within the process of knowledge production.

Dussel's decolonisation project is above all a rejection of the narrative of modernity that describes it as a purely intellectual enterprise, apart from a global economic history. In fact, Dussel (1994: 21) specifically takes aim against Habermas's account that the origins of modernity are located in the Reformation, the Enlightenment and the French Revolution. The implications of a Habermasian intellectual history, according to Dussel (1994: 35), is that Latin America, Africa and Asia are of no importance to world history, which is nothing other than a conflation of European 
particularity and world universality. Habermas's attempt to rescue the modern project through 'communicative reason' is also at issue here because defending modernity, as Habermas does, serves to re-circulate the discourses back into Western categories. Although not a decolonial scholar as such, Ángela Iranzo Dosdad (2016) makes good use of this sort of critique, for instance when discussing Habermas's notion of postsecularism. In the article, 'From the secular to the Habermasian post-secular and the forgotten dimension of time in rethinking religion and politics', Iranzo Dosdad (2016: 889-890) argues that post-secularism amounts to a kind of colonialism (by other means), because Habermas's view of post-secularism inherits the Enlightenment notion of progress, where time is privileged over the domain of space. If all cultures, ethnicities and peoples of the world are considered within the context of linear time, there is a tendency to sneak in the frame of rational development as part of the narrative itself. Despite Habermas's (2016: 891) good intentions of including religions within the space of communicative reason, there is an implicit bifurcation between 'secular reason' and 'religious reason', with religion having to go through a process of 'translation' before it can become a 'reasonable religion' with 'secular principles'. Therefore, religions must become 'post-religious' if they are to be taken seriously. As it pertains to Dussel's critique of Habermas, the point here is that a Habermasian vision to save modernist rationality only reinforces the structural myth of modernity, that which is founded on the exclusion and domination of the Other.

Dussel's decolonisation project is also a rejection of post-modernity as postmodernity is still part of the Eurocentric vision of modernity-hence the need for a critique from the 'exterior' (2012: 37). What makes post-modernity even more disturbing for Dussel, however, is that its inclination is to slip into nihilistic and irrational truth claims, which contributes nothing in terms of building a global perspective. While Dussel (1994: 22) accepts the critique of reason as formulated in post-modernity, reason alone is not the problem since rationality is a universal phenomenon. The problem is more that cultural alterity as such has not been made visible in the development of intellectual thought in world history, nor has it been invited to participate in the development of the world that is yet to come. In fact, as we are reminded by Ramón Grosfoguel (2010: 31), one of the leading scholars of the decolonial turn, 'Western social theory is based on the experience of 5 countries (France, England, Germany, Italy, and the United States) that makes only less than 12 percent of the world's population. In order to resolve this problem, we need to ask ourselves, as Dussel ([1977]/1996: 199-200) does in Filosofía de la liberación, 
how we can develop Latin American, African, and even Asian philosophies in a way that empowers those from the underside of modernity without being dependent on Western philosophy while remaining equal to it?

What makes Dussel's critical engagement so unique and different from Badiou and Žižek's post-Marxism is precisely the inclusion of the excluded Other in the overcoming of modernity (and post-modernity). Of course, this does not mean that dialogue is impossible (see Dussel 2011). After all, a good portion of Dussel's work is concerned with reconstructing Marx. In the late 1970s, shortly after first commenting on liberation theology, Dussel began a rereading of Marx, but instead of approaching him from the standpoint of European commentators, he approached him from the standpoint of Latin American 'dependency' (Burton \& Flores Osorio 2011: 24). One of the starting points for Dussel's engagement with Marx's ethical critique of capitalism is found in the distinction between living labour and dead labour (2001: 21). In his exegetical reading of Marx, Dussel (1988: 293-297) insists that alterity is not accounted for in Marx's view of capital as capitalism is only thought to transform and accumulate, leaving little room for the more robust concept of creation. Dussel argues that we must presume that Marx has a concept of 'living labour' to represent the creative source existing outside of capital production, otherwise there would be no basis for praxis. While so-called dead labour is the vampire capital that feeds on living labour, living labour is the creative source and power of human life prior to the system of capital, that which cannot be absorbed by the totality of capital. Since it is the source of capital accumulation, and yet resistant to being fully absorbed by it, living labour becomes a departure for alterity as a critique of modernity, because it represents a perspective of being both inside and outside the system of capital (Dussel 1988: 67-69).

How do we position Dussel's decolonial critique within the history of philosophy? Dussel's mélange of Marxism, Levinasian ethics-first philosophy and liberation theology makes it a unique contribution to the history of philosophy, but it does not necessarily gel with just any theoretical critique mired in the Marxist literature. This is because Dussel's philosophy is a historical critique of Western epistemology, targeting the deep-seated Eurocentric assumptions within modernist philosophy. A rushed marriage between post-Marxism and decolonialism would be somewhat awkward in this regard because the former's demand for a universal foundation already established in modernity would be unpalatable to a decolonial defence of the cultural differences and identities excluded from modernity. This point becomes more glaringly obvious 
when we bring the philosophical offshoots of Dussel's philosophical criticism into the conversation. For instance, Grosfoguel (2008: 201-209), in the article 'Hacia un pluriversalismo transmoderno decolonial', argues that any return to universal truth claims from within the Western philosophical tradition is problematic since the concept of the universal, from Descartes to Marx, has disguised an 'ego-politics of knowledge'. In other words, the universals that were initiated by a Cartesian solipsism left intact a legacy of a faceless, zero-point philosophy, which gave rise to the production of scientific knowledge. As Grosfoguel argues, such a position, which privileges an ego-politics of knowledge over the geo-politics of knowledge, sets in place a view of a world that assumes that only Western traditions have access to universality. At this point, there is no dialogue among epistemologies between different cultures, but rather a monologue, dominated and controlled by those immersed in Western intellectual traditions. This process of epistemological monologue fits rather neatly into what Boaventura de Sousa Santos $(2014:$ 92, 153, 209) calls 'epistemicide', which is defined as the erasure of indigenous cultures, practices, and knowledge through the violent effects of colonial domination. The extermination of epistemologies around the world is not due to the inherent cultural superiority of the West but is the result of a long history of projecting others as intellectually inferior. The central point that is being made here is that if we move forward with post-Marxism as the hegemonic framework for contemporary philosophy, then there is a real possibility for furthering the project of epistemicide because of their commitment to Western universals. But there is another reason for why the decolonial critique is important to uphold, which will be discussed now.

\section{The evidence supporting the myth of modernity}

When we think about why a decolonial critique is useful for the contemporary academic world, one of the things that comes to mind is its overwhelming historical evidence. In order to see how the return to universal truth claims are at risk of repeating the myth of modernity, we will need to discuss the historical link between colonialism, knowledge (the discourses comprising philosophy, religion and science) and racial domination. This history has been told in various ways, but for the purposes of this article we will lay out the evidence by starting with the history of raciology from within modern philosophy and end with a discussion of how it set the stage for colonial domination and the ongoing Western intellectual hegemony we see today. 
One rendition of the argument that links racism and modern philosophy can be found in Peter Park's (2013) book Africa, Asia, and the history of philosophy. The central focus of Park's historical account in this text is to reveal how the bifurcation between 'real philosophy' and 'infantile philosophy' implicit in philosophy departments is a modernist invention. As Park claims (2013: 1-2), within the pursuit to establish the boundaries of philosophy during the modern period were philosophers seeking to exclude non-European thought-relegating the non-European forms of thought to 'pre-history' or to the study of religion. This is because, from the eighteenth century onward, the discipline of philosophy began to tell itself that the history of philosophical knowledge was a march of progress that had started in Greece. Since Africans and Asians were thought to be more primitive than Europeans, modern philosophers would remove their intellectual heritages from the history of philosophy, deeming the people of these lands incapable of doing anything philosophical in nature (Park 2013: 2-3). However, this particular view of intellectual history was not always the standard view within the history of Western philosophy: Prior to Kant and Hegel, it was not uncommon to include non-European traditions in the history of philosophical thought. Friedrich Schlegel (1772-1829), for instance, pioneered comparative philosophy by affirming the reality of 'Oriental philosophy', elevating Asian philosophy to the level of European philosophy (Park 2013: 7). This view was challenged in the 1780s and was replaced by the argument that philosophy can only be thought of as a Greek invention because no other cultural group in history had a word corresponding to the European concept of philosophy (Park 2013: 69).

Park (2013: 1-4) insists that the reason for the exclusion of non-Western philosophy was racial. Kant, who borrowed from anthropological theories of racial classification, ${ }^{4}$ argued that Indians (referred to by him as the 'Hindu race') could never develop philosophy as they lacked the capacity to do so. Only whites are able to do science or deal with abstract concepts since they had brought about all the revolutions in human history. In other words, the real agents of history, the ones facilitating or contributing to historical progress, are white Europeans (Park 2013: 94). Park's discussion of Kant's raciology coheres with what many other critical race scholars and decolonial theorists have discovered. Grosfoguel (2008: 203-204), for instance, has found that Kant's racist views are consistent with his own concept of transcendental reason. That is, from a Kantian viewpoint, the power to define what is universal for everyone on the planet is exclusive to white European men, precisely because transcendental reason is found only among this demographic. 
But why are non-Europeans considered to be incapable of philosophy? And why is the Enlightenment an exclusively European invention? As Dussel (1994: 13-14) discovered in his own historical investigation, Kant held the belief that non-European cultures are too immature (Kindheit) to have philosophical thought and have a lazy and cowardly ethos that prevents them from developing rationality. Starting with Kant's raciology, the American Indians, negroes and Asians would represent inferior stages of humanity (Chukwudi Eze 1997: 124-125), while Europe's destiny would be to bring these racial groups to a state of rational enlightenment (Dussel 2007: 143144).

Relevant historical literature also demonstrates Hegel's complicity with this particular racial hierarchy, reinforcing the binary between 'real philosophy' and 'infantile philosophy'. Park $(2013: 8-9,148)$ claims that Hegel's dismissal of 'Oriental philosophy' was a by-product of his hostility towards comparative philosophy. Hegel was rather defensive against those who compared his work to that of the Arab and Muslim theosophers and found that one way to resist these comparisons was to write Asia (and Africa) out of the history of philosophy. History was not a system of repetition, but a progressive development of thought, and given that 'Oriental philosophy' was no different from 'Oriental religion', it could not be included in the domain of philosophy. While Hegel did not outright exclude Asian thought, as Park (2013: 150) concedes, his insistence that philosophy began in Greece did. Given that Asia had no connection to Greek philosophy (which was deemed 'the true philosophy'), 'Oriental philosophy' could not be treated as an equal to European philosophy, which signalled its inferior stage of rational development. ${ }^{5}$ Dussel's (1994: 14-20) reading of Hegel confirms Park's historical account, claiming that Hegel's notion of development (Entwicklung) contains a linear structure that not only places Asia in a state of immaturity, but completely bans Africa and Latin America from the narrative of world history itself. In Dussel's opinion, Western imperialism and its concomitant racial domination that took place during the 19th century was already woven into the fabric of Hegelian ontology.

Kant and Hegel's racial hierarchy are, however, mere parts of a broader range of discourses and binaries legitimising Western domination over the periphery. For instance, the racial discourses on Asia and Africa that informed the exclusion of non-European philosophy by German Idealism not only reflects and reinforces the Enlightenment notion of progress but seeks to reproduce another hidden binary established in the myth of modernity: the secular and religious binary. This is because 
the exclusion of African and Asian thought from the history of philosophy has been dependent on the reproduction of a secular view of the world, where progress equates to freedom from superstition and the dogmas associated with religious traditions. Of course, in continental philosophy, religion is not always viewed as an inferior mode of existence because there are many philosophical accounts seeking to justify the logical existence of religion, but when dealing with Asia and Africa in the context of intellectual history, where reason is often thought to be subsumed by religious knowledge, there is a tendency among more 'literal secularists' to fall back on the secular-religion binary as the primary judgment of critical thought and regenerate the Kantian and Hegelian view of rational progress and its naturalisation of the development of world history. Although the history of Asian and African thought does not divide the secular and the religious in discrete compartments, a duality exists within the Western narrative where the peoples of Asia and Africa are thought to live in history, in a static state of time, and are thus reduced to 'objects of textual investigation' while the progressive West is thought to be made up of free-thinking individuals who are believed to be the real creators of history. Western philosophy appears to be outside of history (and this point is to some extent reinforced by the hermeneutics of faith), and non-Western philosophy appears to be 'stuck in history' as products of tradition (a point that is to some extent reinforced by the hermeneutics of suspicion as deployed in the social sciences) (see King 1999: 1-23).

It cannot be denied that there are many factors that play into this history of philosophical exclusion. Other than its ties to scientific racism, philosophy has had ties to scientific accounts of religion, which has had ties to colonial history, which in a feedback loop, reconnected itself back to scientific racism. One of the implications of this 'chain of causation' is the point that 'to theorize religion is simultaneously to theorize race' (Hart 2017: 569). What this means is that the theorisation of religion also has its roots in the rank ordering of races and ethnicities, where Asian and African cultural and religious thought, which have been viewed as stages in the history of intellectual development, are part of the story of imperial conquest. William David Hart (2017: 563) succinctly summarises this process when he says that 'white supremacy, the transatlantic slave trade, and African colonization, as artifacts of that desire [imperial desire], are foundational events in the emergence of theories of religion'. For Hart, and for many post-colonial and decolonial scholars, it is problematic to view the theorisation of religion apart from the history of racialisation in the context of colonial control. This is not to say that the category of religion is 
equivalent to the category of race; rather, the point is more that the history of race and colonialism in the theorisation of religion as a scientific object is linked to what decolonialists have called 'epistemic racism'.

According to Grosfoguel (2013: 75), epistemic racism is the rejection of all critical interventions derived from epistemologies that originate in non-Western traditions. The assumption is that the knowledge produced within non-Western traditions is categorically inferior to Western forms of knowledge. Eurocentrism as one type of epistemic racism has dominated Western universities for so long that it has become normal to subordinate, reduce and discard non-Western knowledge without much justification. In fact, foundational to the knowledge structures of Western universities is this process of eradicating the knowledge systems of the subaltern, because it maintains the intellectual hegemony of the West. Grosfoguel (2010:30-31) claims that epistemic racism is one of the most hidden forms of racism and perhaps the most pervasive as it begins with the purported 'objective neutrality' of scientific discourse. Hidden within the view of objectivity are the loci of enunciation of the speakers: that the inferiorised are pre-emptively disqualified from developing 'real knowledge' because they are thought to be the 'objects of knowledge' and not the producers of knowledge. Rather, the 'real producers' of knowledge are the hegemonic actors within a colonial relationship.

Echoing Dussel's view, Grosfoguel (2010:35-36) tells us that the epistemic privilege imbricated in epistemic racism also begins with the history of the colonisation of the Americas. The elimination of non-Western forms of knowledge, such as indigenous knowledge or spirituality, was implemented by the colonial process in the belief that the indigenous population was barbaric. Since indigenous people were thought to be without religion, which was believed to be a mark of inferiority, colonial expansion was necessary for those communities to become enlightened. While the term 'race' was not conventionally in use during this period, the debate surrounding whether or not the indigenous had souls was already implicitly engaging the discourse of race, because what was ultimately in question was the nature and credibility of the object of investigation - the indigenous themselves. Here one should keep in mind, as Katrin Flikschuh (2018: 101) claims, that much of racism, especially if it involves the African continent, expands beyond the discourses on skin colour or phenotypic features. The concern of place and function of the idea of a geographical space within the Western imagination is often couched within the framework itself in determining a notion of backwardness. While the phenotype of the indigenous peoples mediated 
the discussion of race relations in the colonisation of the Americas, religion and culture were the things that were really on trial. Within this context then, some of the earliest forms of racist discourse involving the conquest of the Americas were not exclusively colour-based but articulated within and around the thematics of religion or theology (Grosfoguel 2013: 80-83). Grosfoguel explains:

Contrary to the contemporary common sense, "color racism" was not the first racist discourse. "Religious racism" ("people with religion" vs. "people without religion" or "people with soul" vs. "people without a soul") was the first marker of racism in the "Capitalist/Patriarchal Western-Centric/Christian-centric modern/colonial world-system" formed in the long 16th century. (2013: 81)

Therefore, the very questioning of indigenous 'theology' or spirituality among the colonialists masked a political inversion. In other words, the essentialisation of the indigenous led to a championing of Western epistemology that would seek to erase indigenous intellectual thought.

The power of this epistemological erasure dates back to the Christian philosophers associated with the conquest of the Americas, but develops more formally with the ego-paradigm of Descartes's solipsistic consciousness (see Dussel 2008). Descartes, who was inspired by the Christian philosophy that justified Spanish colonialism, viewed the mind and body as being different substances, which provided the framework for further colonial expansion because it allowed the unconditioned mind (apart from the body) to be thought of as 'similar to the Christian God, floating in heaven, undetermined by anything terrestrial and that it can produce a knowledge equivalent to a God-Eye view' (2013: 76). The universalisation of the 'I' in the Cogito had replaced God as the foundation of knowledge, therefore leading to a secularisation of the Christian view of God. But this 'I' assumed a production of knowledge from nowhere, from a standpoint of zero. With no situated context, the Cogito produces a knowledge that is God-like, and sets the stage for an imperialistic being, because it assumes that the 'I' exists as the centre of the world (Grosfoguel 2013: 77). The rest of the world is disposable and expendable, ready to be consumed, controlled and dominated by the ego-subject, because everything is subordinate to it. Therefore, the philosophical foundation of Western modernity, which privileges an ego-politics of knowledge above all else, cleared the way for Western subjectivity to represent its own singular knowledge as the only one capable of achieving a consciousness that 
is universal while dismissing non-Western knowledge as particularistic (Grosfoguel 2011: 5-6). However, if there is a way to dismantle the myth of modernity, as Grosfoguel, Dussel and other decolonialists tell us, the knowledge we produce moving forward must disrupt viewpoints that assume that only Western intellectual traditions have access to universality.

\section{Conclusion: Finding the emerging voice of alterity in global history}

To what extent should the decolonial critique take post-Marxism seriously? In order to answer this question, we have to consider the praxes of decolonialism and post-Marxism in their aims to overcome modernity and post-modernity. While the decolonial critique is often partnered with a transmodern approach, where the peripheral culture-those dominated by the imperial cultures-are the point of departure for intercultural dialogue (see Dussel 2012: 28-59), post-Marxism is more committed to a 'practice of emancipation' that can begin anywhere in the capitalist world. Given how variegated the latter is, it is difficult to make generalisations here, but from Badiou's ethics (2001) to Žižek's politicisation of ethical violence (see Rayman 2017), an awareness to 'build solidarity' across the world is thought to be needed in order to enact a new form of communism (although it is not entirely clear what that is). Agreement can be found among the decolonialists in the call to dismantle neo-liberal capitalism and build solidarity movements around the world, but among the post-Marxists in particular there is no need to ground this transformation in the cultural, philosophical and religious traditions at the periphery. In this sense, these two groups are fundamentally at loggerheads with regard to their notions of critique: while post-Marxism seeks to reclaim a universal ontology (qua 'third'), Dussel (1998: 460-462), and many other decolonialists, move from an ethics-first critique, insisting that ontology does not precede ethics, but rather follows from an articulation of the good. While an alliance is certainly possible, how this all plays out in history will be contested because the decolonial critique cannot advance its political vision without cultural differences and marginalised identities as part of the new chapter in global history. In other words, to 'reverse' the historical effects of global history, there needs to be a reclamation of indigenous epistemologies, not a continuation of its elimination. But if the post-Marxists have it their way, it would be difficult to imagine any resistance against epistemicide because of its implicit calling for a philosophical vanguard in order to bring about historical change. The fear here is that the post- 
Marxist approach may in fact be pregnant with philosophical implications that could repeat the myth of the European modernity within their pursuit to re-assert universals. This does not suggest that nothing can be learned from post-Marxism: their critique of post-structuralism certainly gives us food for thought and there is certainly a danger to the collective impulses of identitarians demanding full loyalty to its political discourse and deeming all critics as racists or cultural chauvinists. However, the pressing question of today should not be concerned with the divisions between identity politics and the post-Marxist critique then, but with how to weave the problem of capitalism and the problem of cultural differences into a coherent mode of inquiry. The 'third position' between these two viewpoints should therefore sublate the post-Marxist critique and decolonial theory as it heads towards the transmodern pluriverse.

As we move closer to building this 'third position', we should also remind ourselves of the need to maintain the distinction between the post-colonial critique and decolonial theory. While the central aim of the former is to bring to the forefront the cultural, political and social consequences of the control and exploitation of colonised people and their lands through an investigation of the cultural and literary discourses of imperial powers, the central aim of the latter is to politicise the very epistemologies foundational to the colonial project that initiated European modernity. Instead of merely criticising the imperial terrors of European modernity, which is the standard practice of the post-colonial movement, the goal with the decolonial critique is to completely undermine the epistemological basis that generates the frameworks of modernity, thus seeking to introduce the subaltern and their concomitant epistemology to knowledge production. The ethical task of decolonialism is therefore to overcome the European constructions internal to post-colonial methodologies by resisting the reproduction of epistemologies that can be characterised as Eurocentric while pursuing a reconstruction of localised epistemologies. In this sense, the decolonial methodology is irreducible to the assumptions featured in the post-colonial movement, which is more or less a shadow critique of European modernity. Dussel was of course trained mostly in European philosophy, which presents a challenge for the decolonial movement, but as Alcoff (2016: 22-30) reminds us, Dussel's methodological shift to liberation theology also offers us an account of how indigenous knowledge can transfer the power from the core to the periphery. I conclude by pointing out that if we are serious about the need to democratise epistemology through a transmodern pluriverse, then we need 
to think through the implications of those philosophical viewpoints we appropriate along the way, like in the case of post-Marxism, otherwise we are at risk of repeating the myths of modernity.

\section{Endnotes}

1. Some might raise objections to the term 'post-Marxism', and perhaps for good reason, but in the absence of consensus among scholars on what we should call this group of thinkers, I will use Nelson Maldonado-Torres's label throughout this article.

2. Badiou and Žižek are philosophers who have achieved celebrity-like status and have managed to shape the debates of the time by controlling the language game of the academic world.

3. Although Fredric Jameson is far more sympathetic to Dussel's project than any other post-Marxist.

4. These anthropological classifications of race assisted the development of scientific racism.

5. The same was also said about Hegel's conception of religion, where Asian religions were viewed as primitive, while Christianity was viewed as an 'absolute religion'. See Enrique Dussel (2008). Meditaciones anti-Cartesianas: Sobre el origen del anti-discurso filosófíco de la modernidad. Tabula Rosa, 9 (JulioDiciembre): 158-159. 


\section{References}

Alcoff, L.M. (2012). Enrique Dussel's Transmodernism. Transmodernity (Spring): 60-68.

Alcoff, L.M. (2016). What would it mean to decolonize pedagogy?: Enrique Dussel's pedagogics of liberation. In Levinson, N. (ed.), Philosophy of education (pp. 1931). Urbana I: Philosophy of Education Society.

Badiou, A. (2001). Ethics: An essay on the understanding of evil, trans. Peter Hallward. London: Verso.

Badiou, A. (2003). Saint Paul: The foundation of universalism, trans. Ray Brassier. Stanford: Stanford University Press.

Badiou, A. (2006). Being and event, trans. Oliver Feltham. London: Continuum.

Burton, M. and Osorio Flores, J. M. (2011). Introducing Dussel: The philosophy of liberation and a really social psychology. PINS, 41: 20-39.

Chukwudi Eze, E. (1997). The color of reason: The idea of "race" in Kant's anthropology. In Chukwudi Eze, E. (ed.), Postcolonial African philosophy: A critical reader (pp. 103-131). Cambridge: Blackwell Publishers.

De Sousa Santos, B. (2014). Epistemologies of the South: Justice against epistemicide. London and New York: City Routledge.

Dussel, E. ([1977]/1996). Filosofía de la liberación. Bogota: Editorial Nueva America.

Dussel, E. (1988). Hacia un Marx desconocido: Un comentario de los Manuscritos del 61-63. Iztapalapa: Siglo XXI.

Dussel, E. (1994). 1492 El encubrimiento del Otro: Hacia el origen del 'mito de la modernidad'. La Paz: Plural Editores.

Dussel, E. (1998). Ética de la liberación en la edad de la globalización y de la exclusión. Madrid: Trotta.

Dussel, E. (2001). The four drafts of capital: Toward a new interpretation of the dialectical thought of Marx. Rethinking Marxism, 13(1): 10-26.

Dussel, E. (2006). 'The Politics' by Levinas: Toward a 'critical' political philosophy. In A. Horowitz \& G. Horowitz (eds), Difficult justice: Commentaries on Levinas and politics (pp. 78-96). Toronto: University of Toronto Press, 2006.

Dussel, E. (2007). Política de la liberación historia mundial y crítica. Madrid: Trotta.

Dussel, E. (2008). Meditaciones anti-Cartesianas: Sobre el origen del anti-discurso filosófíco de la modernidad. Tabula Rosa, 9 (Julio-Diciembre): 153-197. 
Dussel, E. (2011). From critical theory to the philosophy of liberation: Some themes for dialogue. Transmodernity (Fall): 16-43.

Dussel, E. (2012). Transmodernity and interculturality: An interpretation from the perspective of philosophy of liberation. Transmodernity (Spring): 28-59.

Dussel, E. (2019). Analogy and communication. Philosophies, 31(4): 1-23.

Flikschuh, K. (2018). Philosophical racism. Aristotelian Society Supplementary XCII, 92(1): 91-110.

Grosfoguel, R. (2008). Hacia un pluri-versalismo transmoderno decolonial. Tabula Rosa, 9 (Julio-Diciembre): 199-215.

Grosfoguel, R. (2010). Epistemic Islamophobia and colonial social sciences. Human Architecture: Journal of the Sociology of Self-Knowledge, 8(2): 30-31.

Grosfoguel, R. (2011). Decolonising post-colonial studies and paradigms of political-economy: Transmodernity, decolonial thinking, and global coloniality. TRANSMODERNITY: Journal of Peripheral Cultural Production of the LusoHispanic World, 1(1): 1-38.

Grosfoguel, R. (2013). The structure of knowledge in Westernized universities: Epistemic racism/sexism and the four genocides/epistemicides of the long 16th century. Human Architecture: Journal of the Sociology of Self-Knowledge, 11(1): 73 90.

Hart, W.D. (2017). Theorizing race and religion. In R. King (ed), Religion, theory, critique: Classic and contemporary approaches and methodologies (pp. 563-572). New York City: Columbia University Press.

Harvey, D. (1990). The conditions of postmodernity. Cambridge and Oxford: Blackwell.

Iranzo Dosdad, Á. (2016). From the secular to the Habermasian post-secular and the forgotten dimension of time in rethinking religion and politics. Contexto Internacional, 38(3): 887-908.

Jameson, F. (1991). Postmodernism or the cultural logic of late capitalism. Durham: Duke University Press.

King, R. (1999). Indian philosophy: An introduction to Hindu and Buddhist thought. Washington, DC: Georgetown University Press.

Maldonado-Torres, N. (2017). Post-Marxism and religion. In R. King (ed.), Religion, theory, critique: Classic and contemporary approaches and methodologies (pp. 457471). New York City: Columbia University Press.

Park, P. (2014). Africa, Asia, and the history of philosophy: Racism in the formation of the philosophical canon, 1780-1830. Albany: State University of New York Press. 
Rayman, J. (2017). Žižek’s ethics. International Journal of Zizek Studies, 11(2): 1-15. Sanbonmatsu, J. (2004). The post modern prince: Critical theory, left strategy, and the making of a new political subject. New York: Monthly Review Press.

Žižek, S. (2005). Neighbors and other monsters: A plea for ethical violence. In S. Žižek, E. Santner \& K. Reinhard (eds.), The neighbor: Three inquiries in political theology (pp. 134-190). Chicago and London: University of Chicago Press.

Žižek, S. (2008). In defense of lost causes. London and New York City: Verso. 